\title{
Climatic influence on tree wood anatomy: a review
}

\author{
Sudip Pandey ${ }^{*}$ (i)
}

\begin{abstract}
Wood anatomical traits of xylem are the characteristics of tree rings at cellular and subcellular scales providing important insights on structural features and their linkage to the environment. Therefore, studying the relationship between anatomical traits and environmental changes not only provide physiological explanations, but also provide a new vision of studying the adaptation process and response strategies of tree growth to climate. In this paper, I review and synthesize literature on the influence of climatic parameters on wood anatomy from the different geographical regions using recent (2015-2020) published articles on the topic. This paper discusses the relationship between the anatomical features of angiosperm and gymnosperm xylem with climatic factors. Based on the literature, I then purpose to explore the temporal and spatial variations in the anatomical characteristics of xylem tree rings with environmental changes. Also, more studies can be conducted to assess the synergetic and antagonistic effects among different tree-ring proxies and to determine the specific roles and contributions of major climatic factors during different periods of tree-ring formation.
\end{abstract}

Keywords: Angiosperm, Environmental change, Gymnosperm, Wood anatomical traits, Xylem

\section{Introduction}

Climate change is the biggest challenge of this century and is exerting pressure on both plants and animals $[1$, $2]$. An increase in global temperature $\left(\approx 0.2{ }^{\circ} \mathrm{C} /\right.$ decade $)$ along with the rise in $\mathrm{CO}_{2}(2.5+/-0.8 \mathrm{ppm} /$ year $)$ in the atmosphere with the change in precipitation regime may have effects on the structure and function of trees [3-5]. This climatic change interacts with trees during their life leaving a permanent imprint in the woody tissues. Therefore, trees are considered as the most valuable natural archives of past environmental conditions [6-8] showing a unique source for annual variability in forest biomass and carbon allocation $[9,10]$. Thus, there is an increasing interest of researcher in analyzing tree-ring characteristic to better understand tree growth responses to environmental variability and extreme events [11-15].

*Correspondence: sudip.pandey@mbustb.edu.np

Madan Bhandari University of Science and Technology Development Board, Saibu, Bhaisepati, Lalitpur, Nepal
Recent advancements in dendroecology, namely dendroanatomy aim at deciphering the effects of climate on the whole xylogenetic process, i.e., complex process of differentiation and division of cambium with environmental input and formation of new woody tissues [16-18]. Dendroanatomy is defined as the analysis of xylem-cell features along dated tree rings which provide a long-term perspective on the wood formation process [19]. The advancement in sample processing and image analysis allows studying the detailed measurement of multiple traits in wood at decadal to centennial time scales $[20,21]$. This allows the researcher in studying inter-annual variability of vessels/tracheids lumen area or cell wall thickness retrospectively analyzing the cambium phenology with changing environment $[14,22,23]$.

Afterwards, many studies have explored the long-term effects of climate variability on the corresponding yearto-year change in wood anatomical traits and its consequence for gymnosperm $[13,24,25]$ and angiosperm $[15$, 26] physiology and growth. For instance, some authors reported a drought decreases the lumen area leading to 
decline in stem hydraulic conductivity $[27,28]$, whereas others found the opposite $[29,30]$. Two dominant Mediterranean shrub species, Erica multiflora and Globularia alypum grown in the same drought conditions showed contrasting phenology indicating its effects to be species-specific [31, 32]. Researchers also found some tree species in extreme drought conditions produce intraannual density fluctuation $[24,33]$ or distorted and collapsed cells [34], early cessation of cell division [35] and light rings characterized by narrow latewood brand [36]. Drought stress is related to missing rings formation in Himalayan (Betula utilis D. Don) [15, 37] and Tibetan species (alpine Juniper shrub) [38] providing compelling evidence of moisture-triggered xylogenesis. Restricted water availability is not only a limiting factor for growth in warm and dry areas, but also low-temperature control growth at high latitudes and elevation [39]. Elevated carbon dioxide in ring-porous species showed an increase conduit size in earlywood and wood density due to a higher proportion of latewood [40], whereas in coniferous species there is an increase in radial growth but not a large change in wood density and tracheids dimensions $[41,42]$. This shows climatic parameters impact in xylem anatomy of trees and ultimately determine its future scenario. Yet, more studies are needed focusing on different species from different geographical regions.

In this review, I briefly present an overview of interand intra-annual variation in wood structure in response to climatic parameters. This focuses on dendroecologybased xylem anatomy to assess the state of the art in the emerging field and future research. The paper discusses how changing climatic parameters have interactive effects on the xylem anatomy of angiosperm and gymnosperm trees from different geographical regions. Lastly, it gives an idea about the research conducted till now and way forward specifying the research gaps.

\section{Materials and methods}

The literature search was done using an electronic database, google scholar and web of science using the term xylem anatomical traits and climate; climate change and wood anatomy as keywords. The original articles collected from different search engines were compiled. Only peer-reviewed articles based on climatic influence and trees at a different geographical zone with specific methods and result were selected. The printed and online journals registered on the journal website were included for study. Valuable sources of information from news articles, case studies, technical notes, educational materials were excluded as they are not peer-reviewed. To make a concise and systematic review, we choose only articles published in English between 2015 to 2020 (Table 1). I also consider articles that include at least one tree-ring chronology and analyze the relationship with instrumental climate data. The searched articles were imported into Mendeley reference management software (Mendeley Desktop version 1.19.4).

\section{Result}

A total of 240 articles were found through databases and 45 duplicates were removed. The first screening of the articles consisted of reading the title and abstracts and 70 articles were identified as eligible for full text. Also, references to the analyzed paper were accessed to identify other studies that had not been found in the consulted databases. From the 70 articles, 20 of them were selected to make an equal representation of angiosperm and gymnosperms with climatic parameters from different geographical region.

The studies included 19 species (12 angiosperms and 8 gymnosperms) from 8 families (Table 2). Twenty articles from 12 countries were reviewed to understand the response of xylem anatomical traits with changing climate. Studies showed climatic parameters, i.e., temperature and precipitation as main driving factors for the growth and development of plants. The response differs based on origin, climatic condition and the orientation of tree species.

\section{Discussion}

\section{Climatic influence on wood anatomy of trees}

Wood is a porous and fibrous structural tissue found in the stems and roots of trees and woody plants. A tree is composed of a bundle of vessels (for transporting water

Table 1 The inclusion and exclusion criteria

\begin{tabular}{llll}
\hline S no. & Criterion & Eligibility & Exclusion \\
\hline 1 & Literature type & Research articles (journal) & $\begin{array}{l}\text { Review journal articles, book, book chapter, } \\
\text { book series, conference paper, report, } \\
\text { proceeding }\end{array}$ \\
& Language & English & Non-English \\
3 & Timeline & Between 2015 and 2020 & $<2014$ \\
& & Full-length paper peer-reviewed journal & Published abstract \\
\hline
\end{tabular}


Table 2 Articles included in the study

\begin{tabular}{|c|c|c|c|c|c|c|}
\hline Country & Name of plant & Family & Plant type & Measured parameter & $\begin{array}{l}\text { Environmental parameter } \\
\text { considered }\end{array}$ & References \\
\hline Italy & Picea abies & Pinaceae & Gymnosperm & Tracheids & $\begin{array}{l}\text { Temperature and precipi- } \\
\text { tation }\end{array}$ & [23] \\
\hline $\begin{array}{l}\text { North America } \\
\text { (Alaska and } \\
\text { Canada) }\end{array}$ & $\begin{array}{l}\text { Picea glauca (Moench) } \\
\text { Voss }\end{array}$ & Pinaceae & Gymnosperm & $\begin{array}{l}\text { Lumen area and cell wall } \\
\text { thickness }\end{array}$ & Drought & {$[25]$} \\
\hline Canada & Picea mariana & Pinaceae & Gymnosperm & $\begin{array}{l}\text { Cell wall thickness and tra- } \\
\text { cheids size and number }\end{array}$ & $\begin{array}{l}\text { Temperature and precipi- } \\
\text { tation }\end{array}$ & [13] \\
\hline Norway & Picea abies & Pinaceae & Gymnosperm & Cell wall thickness & Drought & {$[50]$} \\
\hline Slovenia & Picea abies & Pinaceae & Gymnosperm & Cell lumen area & $\begin{array}{l}\text { Temperature and precipi- } \\
\text { tation }\end{array}$ & {$[52]$} \\
\hline Italian Alps & Picea abies & Pinaceae & Gymnosperm & Cell lumen area & $\begin{array}{l}\text { Temperature and precipi- } \\
\text { tation }\end{array}$ & [51] \\
\hline Italian Alps & $\begin{array}{l}\text { Larix decidua Mill. } \\
\text { and Picea abies (L.) Karst }\end{array}$ & Pinaceae & Gymnosperm & Xylem anatomy & Temperature & [14] \\
\hline Portugal & Pinus pinaster & Pinaceae & Gymnosperm & $\begin{array}{l}\text { Cell wall thickness, lumen } \\
\text { diameter }\end{array}$ & $\begin{array}{l}\text { Water availability and } \\
\text { temperature }\end{array}$ & {$[53]$} \\
\hline Italy & $\begin{array}{l}\text { Robinia pseudoacacia L. } \\
\text { and } \\
\text { Quercus robur L }\end{array}$ & Fabaceae & Angiosperms & Vessels & $\begin{array}{l}\text { Temperature and precipi- } \\
\text { tation }\end{array}$ & {$[54]$} \\
\hline Italy & $\begin{array}{l}\text { Quercus ithaburensis and } \\
\text { Quercus boissieri }\end{array}$ & Fagaceae & Angiosperms & Vessels & Drought & {$[26]$} \\
\hline Greenland & Betula nana L & Betulaceae & Angiosperms & Vessels & $\begin{array}{l}\text { Temperature and precipi- } \\
\text { tation }\end{array}$ & {$[55]$} \\
\hline Greenland & Betula nana L & Betulaceae & Angiosperms & Vessels & $\begin{array}{l}\text { Temperature and precipi- } \\
\text { tation }\end{array}$ & {$[56]$} \\
\hline Nepal & Betula utilis D. Don & Betulaceae & Angiosperms & Vessels and fibers & $\begin{array}{l}\text { Temperature and precipi- } \\
\text { tation }\end{array}$ & [15] \\
\hline Chile & $\begin{array}{l}\text { Nothofagus pumilio } \\
\text { (Poepp. et Endl.) Krasser }\end{array}$ & Nothofagaceae & Angiosperms & Vessels & Temperature and moisture & {$[58]$} \\
\hline Chile & $\begin{array}{l}\text { Embothrium coccineum } \\
\text { (Evergreen) and Nothofa- } \\
\text { gus antarctica (Decidu- } \\
\text { ous) }\end{array}$ & $\begin{array}{l}\text { Proteaceae } \\
\text { Nothofagaceae }\end{array}$ & Angiosperms & Vessels & Precipitation & {$[57]$} \\
\hline Switzerland/Italy & Ilex aquifolium L & Aquifoliaceae & Angiosperms & Vessel area, number & $\begin{array}{l}\text { Temperature and precipi- } \\
\text { tation }\end{array}$ & {$[59]$} \\
\hline Canada & Populus tremuloides & Salicaceae & Angiosperms & Vessel diameters & $\begin{array}{l}\text { Temperature and precipi- } \\
\text { tation }\end{array}$ & {$[60]$} \\
\hline Spain & $\begin{array}{l}\text { Quercus robur and Quercus } \\
\text { pyrenaica }\end{array}$ & Fagaceae & Angiosperms & Vessels & Temperature & [61] \\
\hline Poland & Quercus robur & Fagaceae & Angiosperms & Vessel area and number & Temperature & {$[62]$} \\
\hline Brazil & Tectona grandis & Lamiaceae & Angiosperms & Earlywood vessels (EWV) & $\begin{array}{l}\text { Temperature and precipi- } \\
\text { tation }\end{array}$ & {$[63]$} \\
\hline
\end{tabular}

within trees) and its wall composed of cellulose glued together with lignin. These woods are classified based on cellular structure as softwood (derived from conifer tree-gymnosperm) and hardwood (derived from broad-leaved trees-angiosperm) (Fig. 1). These cellular structures are commonly known as xylem which is complex tissues composed of tracheids (narrow cells), vessels (wider cells), xylem parenchyma (live cells) and xylem fibers (dead cells) $[10,22]$. Out of these four, tracheids and vessels are chief conducting dead cells in the xylem.
Xylem anatomical features of gymnosperm are relatively simple composed of earlywood and latewood tracheids, whereas angiosperm has more complex structures with specialized structures called vessels for conducting sap upward.

Studies showed the anatomy of the xylem affects functional properties such as hydraulic safety and efficiency $[43,44]$. Therefore, changes in xylem anatomy strongly determine trees performance, survival and capacity to fix carbon $[45,46]$. Xylem shape is affected by the synergic 
a Angiosperm

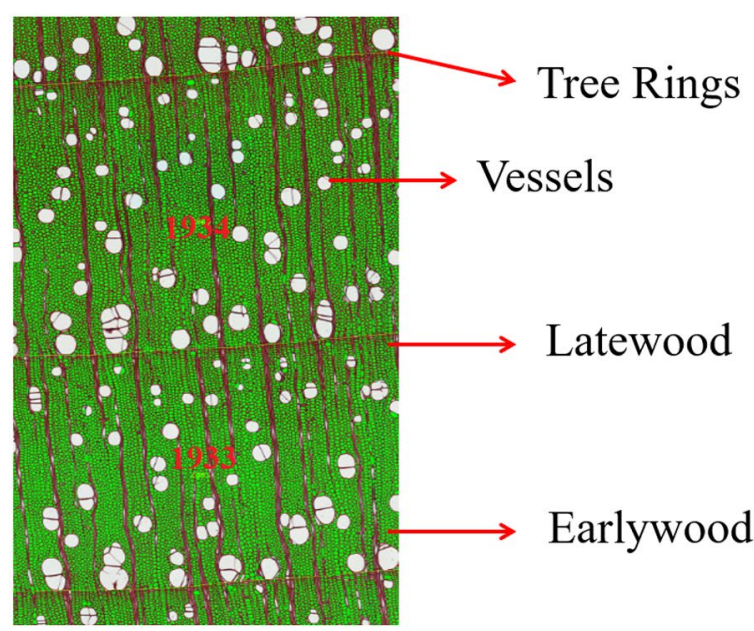

Betula utilis D. Don b Gymnosperm

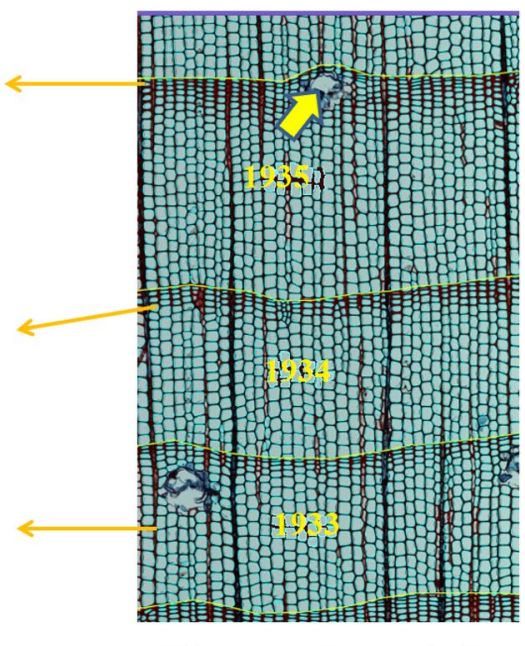

Pinus sylvestris L.

Fig. 1 Cut-out image showing xylem anatomical features (vessels, latewood, earlywood, tree rings) a Image of Betula utilis D. Don, Angiosperm b Image of Pinus sylvestris L., Gymnosperm. The arrow in $\mathbf{b}$ depicts a parenchyma cell of a resin duct

effects of endogenous (genetic) and exogenous (environmental) factors $[47,48]$. Therefore, it is necessary to critically evaluate and discuss the effects of ongoing environmental changes to wood anatomical traits.

In gymnosperm, most of the wood is composed of tracheids, which simultaneously provide vascular transport and mechanical support [49]. The tracheid size of Picea abies from the Italian Alps has been influenced by climate conditions in the growing season. They found that early-summer temperature affects cell enlargement at higher elevation, whereas at lower elevation water availability helped in the enlargement of the cell [23]. A similar study was conducted by Rosner et al. [50] on Norway spruce (Picea abies) which showed trees from the coldest site was smaller with the largest lumen area indicating the species to be probably less resistant under extreme climatic events.

Also, Norway spruce from Italian Alps, Slovenia and the Czech Republic showed lumen dimension of earlywood tracheids to be positively affected by precipitation in the previous autumn and early summer of the current growing season [51, 52]. In white spruce [Picea glauca (Moench) Voss] lumen area and cell wall thickness were found higher sensitive to drought indicating a plastic adaptation to shift in growth-limiting conditions mainly stabilizing latewood cells [25]. A similar study conducted on black spruce (Picea mariana) from the boreal forest of Canada showed cell number $(\mathrm{CN})$ and cell wall thickness (CWT) to be positively affected by spring and summer daily mean and maximum temperature at northern sites.
Moreover, they found latent impacts of water availability on xylem traits [13].

Carrer et al. [14] investigated wood anatomical traits of two high-elevation conifers (Larix decidua Mill., Picea abies (L.) Karst.) and found xylogenesis in the species benefits from warm temperature depending on the timing of cell production. A study on CWT and LD of Pinus pinaster from Portugal showed a crucial role of water availability on cambial activity and wood formation. They found that $P$. pinaster under water-limited environments appears to adjust LD, while in temperature-limited environments the species adjust CWT [53]. This shows that even though conifer wood at first glance is a rather uniform material at the microscopic and functional levels, it is quite varied and gives rise to important differences in capabilities of woody parts in response to change in climatic parameters.

Woody angiosperm is widely divergent in its xylem cellular makeup. For example, xylem hydraulic traits of native Quercus robur L. was more sensitive to previoussummer drought than those of alien Robinia pseudoacacia L. This suggests that $R$. pseudoacacia L. might be more competitive under future drier conditions [54]. Two deciduous species namely Quercus ithaburensis and Quercus boissieri from the southeastern Mediterranean showed abundant precipitation and low temperature from November to April benefit the xylem formation [26]. The dry years strongly limit vessels size and number in Q. ithaburensis compared to Q. boissieri, making one highly resilient and the other highly resistant. 
Betula nana L. vessel lumen area from western Greenland showed influence by spring and summer temperature, whereas vessel grouping was driven by winter temperature [55]. Similarly, Hollesen et al. [56] documented that Betula nana growth is positively influenced by winter temperature as important as summer.

High-altitude angiosperm, Betula utilis D. Don of Nepal showed vessel area to be positively associated with March precipitation and fiber area negatively correlated with temperature during the previous and current season [15]. This showed that the fibers get narrower when the vessels are wider. Wood anatomy of southern Chilean species Embothrium coccineum (Evergreen) and Nothofagus antarctica (Deciduous) showed an increase in vessels density with dryness without changes in estimated hydraulic conductivity [57]. Similarly, another Chilean deciduous broadleaf tree Nothofagus pumilio (Poepp. et Endl.) Krasser showed an increase in vessels density and a decrease in vessels composition with lower temperature, however, the xylem-specific hydraulic conductivity remained constant across elevation and latitude [58]. Rita et al. [59] study xylem traits of Ilex aquifolium L. from Switzerland (mesic site) and Italy (drought-prone site). They found the species from Switzerland were primarily affected by temperature; however, precipitation had the greatest effects at the Italian site showing a positive relationship with potential hydraulic conductivity (Ks) and negative with xylem vulnerability $(\mathrm{Vx})$. This concludes that compared with the drought-prone site, the mesic climatic condition favored xylem traits associated with hydraulic efficiency showing the stronger influence on anatomical traits.

Populus tremuloides, a deciduous Canadian species vessel diameter showed strong relationships primarily with mean annual precipitation and less association with temperature. Also, vessels diameters were highly plastic in response to different environments and varied with summer moisture availability [60]. The temperate Quercus robur earlywood vessels were exclusively affected by temperature whereas they were more independent in the sub-Mediterranean Quercus pyrenaica [61]. A similar study was conducted in Q. robur from northern Poland and found vessel area to have a significant positive correlation to minimum winter temperatures to reduce damage to the root systems [62]. Tectona grandis earlywood vessels from Brazil showed a significant correlation with summer season temperature and precipitation for efficient water transport. They found spring conditions to have a direct influence on the formation of earlywood vessels suggesting warmer temperature to favor efficient water transporting system [63]. This concludes that the whole xylem formation process including earlywood and latewood might be most affected by the climate during the current growing season. Temperature seems to be the most influencing factor for the timing of earlywood and latewood formation during the xylem formation process according to the physiological status of the trees.

\section{Conclusion}

Climate warming is shown to be more apparent impacting tree growth and xylem anatomical traits. Wood xylem traits, therefore, help to understand and predict woody plant responses to global environmental change and provide an opportunity for understanding the hydraulic safety margin of trees. This review showed that the xylem is more sensitive to environmental factors and depends on species, e.g., deciduous species did not show a significant difference in wood structure, however, evergreen species showed higher variation indicating a higher sensitivity to varying climatic conditions. Moreover, it provides great potential for a multidisciplinary approach in wood science to provide an answer to a question related to tree performance under changing environmental conditions [64]. In addition to wood anatomical traits study, there is a promising research avenue of investigating spatial and temporal variation in wood anatomy to understand genetic and phenotypic variation. Lastly, a better understanding of the mechanisms on how climate affects wood anatomical traits facilitate the prediction of climate change impacts at a local regional and global level.

\section{Abbreviations}

$\mathrm{CO}_{2}$ : Carbon dioxide; CWT: Cell wall thickness; CN: Cell number; Ks: Potential hydraulic conductivity; LD: Lumen diameter; Vx: Xylem vulnerability.

\section{Acknowledgements}

The author would like to thank Madan Bhandari University of Science and Technology Development Board (MBUSTB) for providing the opportunity to carry out this research.

\section{Authors' contributions \\ SP conceptualized the research, conducted a literature review and wrote the manuscript. The author read and approved the final manuscript. \\ Funding \\ None. \\ Availability of data and materials \\ The dataset analyzed during the current study are available from the cor- responding author on request. \\ Declarations}

Ethics approval and consent to participate

Not applicable.

Consent for publication

Not applicable.

Competing interests

The author declares that there is no competing interests. 
Received: 15 October 2020 Accepted: 26 February 2021

Published online: 16 March 2021

\section{References}

1. Root TL, Price JT, Hall KR, Schneider SH, Rosenzweig C, Pounds JA (2003) Fingerprints of global warming on wild animals and plants. Nature 421:57-60. https://doi.org/10.1038/nature01333

2. Willis KJ (2017) State of the World's Plants 2017. Royal Botanic Gardens, Kew

3. Menezes-Silva PE, Loram-Lourenço L, Alves RDFB, Sousa LF, da Almeida SE, S, Farnese FS, (2019) Different ways to die in a changing world: Consequences of climate change for tree species performance and survival through an ecophysiological perspective. Ecol Evol 9:11979-11999. https ://doi.org/10.1002/ece3.5663

4. Vennetier M, Girard F, Taugourdeau O, Cailleret M, Caraglio Y, Sabatier S-A, Ouarmim S, Didier C, Thabeet A (2013) Climate Change Impact on Tree Architectural Development and Leaf Area. In: Singh Bharat Raj (ed) Climate Change - Realities, Impacts Over Ice Cap, Sea Level and Risks. IntechOpen Limited, London, pp 103-126

5. IPCC (2014) Climate Change 2014: Synthesis Report. Contribution of Working Groups I, II and III to the Fifth Assessment Report of the Intergovernmental Panel on Climate Change. Gian-Kasper Plattner

6. Swetnam TW, Brown PM (2011) Climatic Inferences from Dendroecological Reconstructions. In: Hughes M, Swetnam T (eds) Dendroclimatology. Developments in Paleoenvironmental Research, Springer, Dordrecht, pp 263-295

7. Franke J, Frank D, Raible CC, Esper J, Brönnimann S (2013) Spectral biases in tree-ring climate proxies. Nat Clim Change 3:360-364. https://doi. org/10.1038/nclimate1816

8. Bradley RS (2011) Natural archives, changing climates. Science 7:21-25. https://doi.org/10.2436/20.7010.01.104

9. Babst F, Alexander MR, Szejner P, Bouriaud O, Klesse S, Roden J, Ciais P, Poulter B, Frank D, Moore DJP, Trouet V (2014) A tree-ring perspective on the terrestrial carbon cycle. Oecologia 176:307-322. https://doi. org/10.1007/s00442-014-3031-6

10. Wimmer R (2002) Wood anatomical features in tree-rings as indicators of environmental change. Dendrochronologia 20:21-36. https://doi. org/10.1078/1125-7865-00005

11. Battipaglia G, De Micco V, Brand WA, Saurer M, Aronne G, Linke P, Cherubini P (2014) Drought impact on water use efficiency and intra-annual density fluctuations in Erica arborea on Elba (Italy). Plant Cell Environ 37:382-391. https://doi.org/10.1111/pce.12160

12. Rossi S, Morin H, Deslauriers A, Plourde PY (2011) Predicting xylem phenology in black spruce under climate warming. Glob Change Biol 17:614-625. https://doi.org/10.1111/j.1365-2486.2010.02191.x

13. Puchi PF, Castagneri D, Rossi S, Carrer M (2020) Wood anatomical traits in black spruce reveal latent water constraints on the boreal forest. Glob Change Biol 26:1767-1777. https://doi.org/10.1111/gcb.14906

14. Carrer M, Castagneri D, Prendin AL, Petit G, von Arx G (2017) Retrospective analysis of wood anatomical traits reveals a recent extension in tree cambial activity in two high-elevation conifers. Front Plant Sci 8:737. https://doi.org/10.3389/fpls.2017.00737

15. Pandey S, Carrer M, Castagneri D, Petit G (2018) Xylem anatomical responses to climate variability in Himalayan birch trees at one of the world's highest forest limit. Perspect Plant Ecol Evol Syst 33:34-41. https ://doi.org/10.1016/j.ppees.2018.05.004

16. Rossi S, Morin H, Deslauriers A (2012) Causes and correlations in cambium phenology: towards an integrated framework of xylogenesis. J Exp Bot 63:2117-2126. https://doi.org/10.1093/jxb/err423

17. Fukuda H (1996) Xylogenesis: Initiation, progression, and cell death. Annu Rev Plant Physiol Plant Mol Biol 47:299-325. https://doi.org/10.1146/ annurev.arplant.47.1.299

18. Liang E, Balducci L, Ren P, Rossi S (2016) Xylogenesis and Moisture Stress. In: Kim SS, Funada R, Singh AP (eds) Secondary Xylem Biology: Origins, Functions, and Applications, 1st edn. Elsevier Inc., United States, pp 45-58

19. Fonti P, Von Arx G, García-González I, Eilmann B, Sass-Klaassen U, Gärtner $H$, Eckstein D (2010) Studying global change through investigation of the plastic responses of xylem anatomy in tree rings. New Phytol 185:42-53. https://doi.org/10.1111/j.1469-8137.2009.03030.x
20. von Arx G, Carrer M (2014) ROXAS - A new tool to build centuries-long tracheid-lumen chronologies in conifers. Dendrochronologia 32:290-293. https://doi.org/10.1016/j.dendro.2013.12.001

21. Prendin AL, Petit G, Carrer M, Fonti P, Björklund J, Von Arx G (2017) New research perspectives from a novel approach to quantify tracheid wall thickness. Tree Physiol 37:1-8. https://doi.org/10.1093/treephys/tpx037

22. von Arx G, Crivellaro A, Prendin AL, Cufar K, Carrer M (2016) Quantitative wood anatomy-practical guidelines. Front Plant Sci 7:781. https://doi. org/10.3389/fpls.2016.00781

23. Castagneri D, Fonti P, Von Arx G, Carrer M (2017) How does climate influence xylem morphogenesis over the growing season? Insights from long-Term intra-ring anatomy in Picea abies. Ann Bot 119:1011-1020. https://doi.org/10.1093/aob/mcw274

24. Pacheco A, Camarero JJ, Carrer M (2016) Linking wood anatomy and xylogenesis allows pinpointing of climate and drought influences on growth of coexisting conifers in continental Mediterranean climate. Tree Physiol 36:502-512. https://doi.org/10.1093/treephys/tpv125

25. Lange J, Carrer M, Pisaric MFJ, Porter TJ, Seo JW, Trouillier M, Wilmking M (2020) Moisture-driven shift in the climate sensitivity of white spruce xylem anatomical traits is coupled to large-scale oscillation patterns across northern treeline in northwest North America. Glob Change Biol 26:1842-1856. https://doi.org/10.1111/gcb.14947

26. Castagneri D, Regev L, Boaretto E, Carrer M (2017) Xylem anatomical traits reveal different strategies of two Mediterranean oaks to cope with drought and warming. Environ Exp Bot 133:128-138. https://doi. org/10.1016/j.envexpbot.2016.10.009

27. Liang W, Heinrich I, Simard S, Helle G, Liñán ID, Heinken T (2013) Climate signals derived from cell anatomy of scots pine in NE Germany. Tree Physiol 33:833-844. https://doi.org/10.1093/treephys/tpt059

28. Olano JM, Linares JC, García-Cervigón Al, Arzac A, Delgado A, Rozas V (2014) Drought-induced increase in water-use efficiency reduces secondary tree growth and tracheid wall thickness in a Mediterranean conifer. Oecologia 176:273-283. https://doi.org/10.1007/s00442-014-2989-4

29. Martin-Benito D, Anchukaitis K, Evans M, del Río M, Beeckman H, Cañellas I (2017) Effects of drought on xylem anatomy and water-use efficiency of two co-occurring pine species. Forests 8:332. https://doi.org/10.3390/ f8090332

30. Eilmann B, Zweifel R, Buchmann N, Fonti P, Rigling A (2009) Droughtinduced adaptation of the xylem in Scots pine and pubescent oak. Tree Physiol 29:1011-1020. https://doi.org/10.1093/treephys/tpp035

31. Llorens L, Peñuelas J, Estiarte M, Bruna P (2004) Contrasting growth changes in two dominant species of a Mediterranean shrubland submitted to experimental drought and warming. Ann Bot 94:843-853. https:// doi.org/10.1093/aob/mch211

32. Bernal M, Estiarte M, Peñuelas J (2011) Drought advances spring growth phenology of the Mediterranean shrub Erica multiflora. Plant Biol 13:252-257. https://doi.org/10.1111/j.1438-8677.2010.00358.x

33. Zalloni E, de Luis M, Campelo F, Novak K, De Micco V, Di Filippo A, Vieira J, Nabais C, Rozas V, Battipaglia G (2016) Climatic signals from intra-annual density fluctuation frequency in Mediterranean pines at a regional scale. Front Plant Sci. https://doi.org/10.3389/fpls.2016.00579

34. Arend M, Fromm J (2007) Seasonal change in the drought response of wood cell development in poplar. Tree Physiol 27:985-992. https://doi. org/10.1093/treephys/27.7.985

35. Eilmann B, Zweifel R, Buchmann N, Graf Pannatier E, Rigling A (2011) Drought alters timing, quantity, and quality of wood formation in Scots pine. J Exp Bot 62:2763-2771. https://doi.org/10.1093/jxb/erq443

36. Liang E, Liu X, Yuan Y, Qin N, Fang X, Huang L, Zhu H, Wang L, Shao X (2006) The 1920 S drought recorded by tree rings and historical documents in the semi-arid and arid areas of northern China. Clim Change 79:403-432. https://doi.org/10.1007/s10584-006-9082-x

37. Liang E, Dawadi B, Pederson N, Eckstein D (2014) Is the growth of birch at the upper timberline in the Himalayas limited by moisture or by temperature? Ecology 95:2453-2465. https://doi.org/10.1890/13-1904.1

38. Liang E, Lu X, Ren P, Li X, Zhu L, Eckstein D (2012) Annual increments of juniper dwarf shrubs above the tree line on the central Tibetan Plateau: a useful climatic proxy. Ann Bot 109:721-728. https://doi.org/10.1093/aob/ mcr315

39. Rossi S, Anfodillo T, Cufar K, Cuny HE, Deslauriers A, Fonti P, Frank D, Gricar J, Gruber A, King GM, Krause C, Morin H, Oberhuber W, Prislan P, Rathgeber CBK (2013) A meta-analysis of cambium phenology and growth: 
Linear and non-linear patterns in conifers of the northern hemisphere. Ann Bot 112:1911-1920. https://doi.org/10.1093/aob/mct243

40. Domec JC, Schäfer K, Oren R, Kim HS, McCarthy HR (2010) Variable conductivity and embolism in roots and branches of four contrasting tree species and their impacts on whole-plant hydraulic performance under future atmospheric $\mathrm{CO}_{2}$ concentration. Tree Physiol 30:1001-1015. https ://doi.org/10.1093/treephys/tpq054

41. Watanabe Y, Wakabayashi K, Kitaoka S, Satomura T, Eguchi N, Watanabe M, Nakaba S, Takagi K, Sano Y, Funada R, Koike T (2016) Response of tree growth and wood structure of Larix kaempferi, Kalopanax septemlobus and Betula platyphylla saplings to elevated $\mathrm{CO} 2$ concentration for 5 years exposure in a FACE system. Trees Structure Funct 30:1569-1579. https:// doi.org/10.1007/s00468-016-1390-9

42. Mccarthy HR, Oren R, Finzi AC, Ellsworth DS, Kim HS, Johnsen KH, Millar $B$ (2007) Temporal dynamics and spatial variability in the enhancement of canopy leaf area under elevated atmospheric $\mathrm{CO}_{2}$. Glob Change Biol 13:2479-2497. https://doi.org/10.1111/j.1365-2486.2007.01455.x

43. Lachenbruch B, Mcculloh KA (2014) Traits, properties, and performance: How woody plants combine hydraulic and mechanical functions in a cell, tissue, or whole plant. New Phytol 204:747-764. https://doi.org/10.1111/ nph.13035

44. Schuldt B, Knutzen F, Delzon S, Jansen S, Müller-Haubold H, Burlett R, Clough Y, Leuschner C (2016) How adaptable is the hydraulic system of European beech in the face of climate change-related precipitation reduction? New Phytol 210:443-458. https://doi.org/10.1111/nph.13798

45. Sperry JS, Love DM (2015) What plant hydraulics can tell us about responses to climate-change droughts. New Phytol 207:14-27. https:// doi.org/10.1111/nph.13354

46. Pandey S, Cherubini P, Saurer M, Carrer M, Petit G (2020) Effects of climate change on treeline trees in Sagarmatha (Mt. Everest, Central Himalaya). J Veg Sci. https://doi.org/10.1111/jvs.12921

47. Downes GM, Drew D, Battaglia M, Schulze D (2009) Measuring and modelling stem growth and wood formation: an overview. Dendrochronologia 27:147-157. https://doi.org/10.1016/j.dendro.2009.06.006

48. Downes GM, Drew DM (2008) Climate and growth influences on wood formation and utilisation. Southern Forests 70:155-167. https://doi. org/10.2989/SOUTH.FOR.2008.70.2.11.539

49. Vaganov EA, Hughes MK, Shashkin AV (2006) Tree-Ring Structure in Conifers as an Image of Growth Conditions. Growth Dynamics of Conifer Tree Rings. Springer-Verlag, Berlin Heidelberg, pp 21-69

50. Rosner S, Svĕtlík J, Andreassen K, Børja I, Dalsgaard L, Evans R, Luss S, Tveito OE, Solberg S (2016) Novel hydraulic vulnerability proxies for a boreal conifer species reveal that opportunists may have lower survival prospects under extreme climatic events. Front Plant Sci 7:831. https:// doi.org/10.3389/fpls.2016.00831

51. Castagneri D, Petit G, Carrer M (2015) Divergent climate response on hydraulic-related xylem anatomical traits of Picea abies along a 900-m altitudinal gradient. Tree Physiol 35:1378-1387. https://doi.org/10.1093/ treephys/tpv085

52. Gricar J, Prislan P, De Luis M, Gryc V, Hacurová J, Vavrčík H, Cufar K (2015) Plasticity in variation of xylem and phloem cell characteristics of Norway spruce under different local conditions. Front Plant Sci 6:730. https://doi. org/10.3389/fpls.2015.00730

53. Carvalho A, Nabais C, Vieira J, Rossi S, Campelo F (2015) Plastic response of tracheids in Pinus pinaster in a water-limited environment: Adjusting lumen size instead of wall thickness. PLoS ONE 10:e0136305. https://doi. org/10.1371/journal.pone.0136305

54. Nola P, Bracco F, Assini S, von Arx G, Castagneri D (2020) Xylem anatomy of Robinia pseudoacacia L. and Quercus robur L. is differently affected by climate in a temperate alluvial forest. Ann For Sci 77:1-16. https://doi. org/10.1007/s13595-019-0906-z

55. Nielsen SS, Von AG, Damgaard CF, Abermann J, Buchwal A, Büntgen U, Treier UA, Barfod AS, Normand S (2017) Xylem Anatomical Trait Variability Provides Insight on the Climate-Growth Relationship of Betula nana in Western Greenland. Arct Antarct Alp Res 49:359-371. https://doi. org/10.1657/AAAR0016-041

56. Hollesen J, Buchwal A, Rachlewicz G, Hansen BU, Hansen MO, Stecher O, Elberling B (2015) Winter warming as an important co-driver for Betula nana growth in western Greenland during the past century. Glob Change Biol 21:2410-2423. https://doi.org/10.1111/gcb.12913

57. García-Cervigón Al, Olano JM, Von Arx G, Fajardo A (2018) Xylem adjusts to maintain efficiency across a steep precipitation gradient in two coexisting generalist species. Ann Bot 122:461-472. https://doi.org/10.1093/ aob/mcy088

58. García-Cervigón Al, Fajardo A, Caetano-Sánchez C, Camarero JJ, Olano JM (2020) Xylem anatomy needs to change, so that conductivity can stay the same: xylem adjustments across elevation and latitude in Nothofagus pumilio. Ann Bot 125:1 101-1112. https://doi.org/10.1093/aob/mcaa042

59. Rita A, Cherubini P, Leonardi S, Todaro L, Borghetti M (2015) Functional adjustments of xylem anatomy to climatic variability: Insights from longTerm llex aquifolium tree-ring series. Tree Physiol 35:817-828. https://doi. org/10.1093/treephys/tpv055

60. Schreiber SG, Hacke UG, Hamann A (2015) Variation of xylem vessel diameters across a climate gradient: Insight from a reciprocal transplant experiment with a widespread boreal tree. Funct Ecol 29:1392-1401. https://doi.org/10.1111/1365-2435.12455

61. Pérez-de-Lis G, Rossi S, Vázquez-Ruiz RA, Rozas V, García-González I (2016) Do changes in spring phenology affect earlywood vessels? Perspective from the xylogenesis monitoring of two sympatric ring-porous oaks. New Phytol 209:521-530. https://doi.org/10.1111/nph.13610

62. Pritzkow C, Wazny T, Heußner KU, Słowiński M, Bieber A, Liñán ID, Helle G, Heinrich I (2016) Minimum winter temperature reconstruction from average earlywood vessel area of European oak (Quercus robur) in N-Poland. Palaeogeogr Palaeoclimatol Palaeoecol 449:520-530. https:// doi.org/10.1016/j.palaeo.2016.02.046

63. Venegas-González A, von Arx G, Chagas MP, Filho MT (2015) Plasticity in xylem anatomical traits of two tropical species in response to intraseasonal climate variability. Trees Structure Function 29:423-435. https:// doi.org/10.1007/s00468-014-1121-z

64. Prendin AL, Carrer M, Bjerregaard Pedersen N, Normand S, Hollesen J, Treier UA, Pividori M, Garbrecht Thygesen L (2021) Chemical signature of Eurois occulta L. outbreaks in the xylem cell wall of Salix glauca L. in Greenland. Sci Total Environ 764:144607. https://doi.org/10.1016/j.scito tenv.2020.144607

\section{Publisher's Note}

Springer Nature remains neutral with regard to jurisdictional claims in published maps and institutional affiliations. 